\title{
UJI TOKSISITAS DAN UJI FITOKIMIA EKSTRAK DAUN KEDONDONG (Spondias dulcis Parkinson)
}

\author{
Nur Hasanah, Arika Handayani \\ Sekolah Tinggi Ilmu Kesehatan Kharisma Persada \\ Tangerang Selatan, 15417 \\ E-mail:nurhasanah@masda.ac.id
}

\begin{abstract}
ABSTRAK
Daun kedondong (Spondias dulcis Parkinson) adalah salah satu tanaman obat yang tumbuh di Indonesia. Penelitian ini bertujuan untuk mengidentifikasi toksisitas ekstrak daun kedondong (Spondias dulcis Parkinson) dan mengidentifikasi senyawa kimia yang terdapat dalam ekstrak daun kedondong (Spondias dulcis Parkinson). Metode yang digunakan dalam penelitian ini yaitu metode BSLT (Brine Shrimp Lethality Test) terhadap larva udang (Artemia salina Leach) menggunakan fase etanol serta fraksi $n$-heksan dan etil asetat dengan konsentrasi 50 ppm, 100 ppm, 200 ppm, 400 ppm, 600 ppm dan 1000 ppm, masing-masing dibuat menjadi 2 lalu ditambahkan dengan 10 larva udang (Artemia salina Leach). Pengamatan dilakukan setelah 24 jam pemberian ekstrak. Data kematian yang diolah dengan analisis probit menunjukkan bahwa fase etanol memiliki nilai $\mathrm{LC}_{50} 56,4806 \mathrm{ppm}$, fase etil asetat memiliki nilai $\mathrm{LC}_{50} 66,9730 \mathrm{ppm}$ dan fase $n$-heksan memiliki nilai LC $_{50} 447,7133$ ppm. Hasil penelitian menunjukkan ketiga fase ekstrak daun Kedondong (Spondias dulcis Parkinson) yang digunakan mempunyai potensi toksik terhadap larva udang (Artemia salina Leach) karena memiliki harga $\mathrm{LC}_{50}<1000 \mathrm{ppm}$. Ekstrak daun Kedondong (Spondias dulcis Parkinson) memiliki kandungan senyawa alkaloid, saponin, tanin, fenolik, flavonoid, triterpenoid, steroid, dan glikosa.
\end{abstract}

Kata Kunci : : Daun Kedondong, Larva Udang (Artemia salina Leach), Metode BSLT (Brine Shrimp Lethality Test)

\begin{abstract}
Kedondong Leaf (Spondias dulcis Parkinson) is one of medicinal plants that is grow in Indonesia. This study aims to identify the toxicity of the extract Kedondong leaf (Spondias dulcis Parkinson) and identify the class of compounds contained in the leaf extract Kedondong (Spondias dulcis Parkinson). The method used in this research is BSLT (Brine Shrimp Lethality Test) of ethanol solvent then continued with the solvent fraction of n-hexane and ethyl acetate which is used was 50 ppm, 100 ppm, 200 ppm, 400 ppm, 600 ppm and 1000 ppm which each concentration was made into 2 then added 10 larvae each (Artemia salina Leach). Observation of dead larvae was performed 24 hours after administration of the extract. Mortality data using probit analysis showed that ethanol extract had $L C_{50}$ value of 56,4806 ppm, ethyl acetate extract had $L C_{50}$ value of 66,9730 ppm and n-hexane extract had $L C_{50}$ value of 447,7133 ppm. The results showed that the three phases of extract Kedondong leaf (Spondias dulcis Parkinson) were used are having potential toxic effect on larvae (Artemia salina Leach) because they have $L C_{50}<1000$ ppm and group of compounds extract Kedondong leaf (Spondias dulcis Parkinson) contains alkaloid, compounds, saponins, tannins, phenolic, flavonoids, triterpenoids, steroids, and glycans.
\end{abstract}

Keywords: Kedondong Leaf, Larvae (Artemia salina Leach), BSLT (Brine Shrimp Lethality Test) Method 


\section{PENDAHULUAN}

Penggunaan obat tradisional serta pengobatan tradisional telah lama dipraktekkan di seluruh dunia, baik di negara berkembang maupun negara maju. Penggunaan obat tradisional oleh penduduk di Perancis mencapai 49\%, Kanada 70\%, Inggris 40\% dan Amerika Serikat $42 \%$. Dukungan WHO terhadap konsep back to nature dibuktikan dengan adanya rekomendasi untuk menggunakan obat tradisional termasuk herbal dalam pemeliharaan kesehatan masyarakat dan pencegahan penyakit, terutama untuk penyakit kronis, penyakit degeneratif dan kanker (Sikulamay., et al, 2016).

Indonesia merupakan negara tropis dengan potensi tanaman yang secara turun temurun digunakan sebagai obat tradisional. Jamu, yang merupakan obat tradisional Indonesia, telah menjadi budaya masyarakat Indonesia sejak berabad silam sebagai bagian dari upaya menjaga kesehatan, menambah kebugaran, dan merawat kecantikan. Industri, usaha dan sub sektor jamu dan obat tradisional serta kosmetik di Indonesia semakin berkembang sejak tahun 2008 melalui kegiatan "Jamu Brand Indonesia" yang dicanangkan oleh Presiden RI 2009-2014 Susilo Bambang Yudoyono pada Gelar
Kebangkitan Jamu Indonesia. Jamu mempunyai peluang besar dengan adanya kekayaan keanekaragaman hayati. Indonesia dikenal secara luas sebagai mega center keanekaragaman hayati (biodiversity) terbesar ke-2 di dunia setelah Brazil, terdiri dari tumbuhan tropis dan biota laut. Di wilayah Indonesia terdapat sekitar 30.000 jenis tumbuhan dan 7.000 di antaranya memiliki khasiat sebagai obat. Sebanyak 2500 jenis di antaranya merupakan tanaman obat (Murdopo, 2014).

Kedondong merupakan tumbuhan tropis yang merupakan famili dari Anacardiaceae. Tanaman ini selain buahnya yang dapat dimanfaatkan, daun dan kulit batangnya dapat digunakan untuk pengobatan kulit yaitu mengatasi kulit perih, borok, dan luka bakar. Analisis kimia tanaman kedondong menunjukkan bahwa daun, kulit batang, dan kulit akar kedondong mengandung senyawa saponin, flavanoid, dan tanin. Kandungan tersebut merupakan senyawa aktif yang bersifat antibakteri. Berdasarkan uji aktivitas antibakteri yang telah dilakukan menunjukkan bahwa daun kedondong memiliki kemampuan untuk menghambat fungsi 
membran sel bakteri (Balqis., et al. 2014).

Skrining fitokimia merupakan cara untuk mengidentifikasi bioaktif yang belum nampak melalui suatu tes atau pemeriksaan yang dapat dengan cepat memisahkan antara bahan alam yang memiliki kandungan fitokimia tertentu dengan bahan alam yang tidak memiliki kandungan fitokimia tertentu. Skrining fitokimia merupakan tahap pendahuluan dalam suatu penelitian fitokimia yang bertujuan untuk memberikan gambaran tentang golongan senyawa yang terkandung dalam tanaman yang sedang diteliti. Metode skrining fitokimia dilakukan dnegan melihat reaksi pengujian warna dengan menggunakan suatu pereaksi warna. Hal penting yang berperan penting dalam skrining fitokimia adalah pemilihan pelarut dan metode ekstraksi (Kristianti., et al, 2008). Skrining fitokimia serbuk simplisia dan sampel dalam bentuk basah meliputi pemeriksaan kandungan senyawa alkaloid, flavonoida, terpenoida/steroida, tanin dan saponin menurut prosedur yang telah dilakukan oleh Harbone (1987) dan Depkes (1995).

Uji toksisitas adalah kemampuan suatu zat kimia dalam menimbulkan kerusakan pada organisme baik pada saat digunakan atau saat berada dalam lingkungan. Secara umum toksisitas dibedakan menjadi 2 jenis, yaitu uji toksisitas umum (akut, subakut/subkronis, kronis) dan uji toksisitas khusus (teratogenik, mutagenik, dan karsinogen). Uji toksisitas bertujuan untuk mengetahui efek toksik dan menentukan batas keamanan suatu senyawa yang terdapat dalam zat-zat kimia, termasuk dalam tumbuh-tumbuhan (Depkes RI, 2000).

Berdasarkan uraian atau penjelasan dan data yang telah disampaikan diatas, maka dapat diketahui dalam penelitian ini peneliti bermaksud untuk melakukan penelitian yang berjudul uji toksisitas dan uji fitokimia ekstrak daun kedondong (Spondias dulcis Parkinson).

\section{METODE}

Instrumen yang digunakan adalah alat-alat laboratorium seperti gelas ukur, water bath, batang pengaduk, cawan petri, erlenmeyer, pinset, pipet tetes, pipet mikro, corong, dan tabung reaksi. Bahan yang digunakan adalah daun Kedondong, Etanol, $n$-Heksan, Etil Asetat, larva udang (Artemia salina Leach), dan air laut.Sampel yang digunakan pada penelitian ini adalah daun Kedondong yang di peroleh dari pohon yang berada di dekat rumah. Daun Kedondong sebanyak $2 \mathrm{~kg}$ dicuci lalu dipotong-potong hingga 
menjadi kecil kemudian di keringkan. Setelah kering lalu di jadikan serbuk dan dimasukkan kedalam bejana maserasi (terlindung dari cahaya), Kemudian di maserasi 24 jam sampai filtrat mendekati bening dengan menggunakan etanol $70 \%$, lalu di saring dengan kapas untuk memisahkan filtrat dan ampasnya. Ampasnya diambil dan direndam kembali menggunakan etanol untuk mengulangi proses maserasi selama 24 jam hingga etanol berubah warna menjadi bening. Selanjutnya, filtrat yang diperoleh diuapkan dengan water bath pada suhu 40-60 ${ }^{\circ} \mathrm{C}$ hingga didapatkan ekstrak kental etanol daun kedondong.

Penyiapan larva udang (Artemia salina Leach) dilakukan dengan menetaskan telur udang menggunakan wadah plastik berbentuk kotak/bulat. Wadah yang diperlukan sebanyak dua buah. Sejumlah 1 liter air laut/air garam dimasukkan ke dalam wadah hingga terendam. Air laut yang digunakan terlebih dahulu diukur $\mathrm{pH}$ dengan kertas lakmus, pH yang digunakan berkisar 8-9. Lalu didiamkan selama 24 jam. Setelah 24 jam, telur akan menetas menjadi larva dan akan bergerak secara alamiah. Kemudian larva yang sehat dan aktif bergerak dipindahkan ke dalam wadah lain dengan keadaan sama (air laut/air garam dengan $\mathrm{pH}$ berkisar 8-9 dan terkena cahaya sebagian). Setelah 24 jam kemudian, larva sudah berumur 48 jam.

Setelah didapatkan larva udang (Artemia salina Leach), dilakukan pembuatan larutan induk 2000 ppm dengan cara Ekstrak kental etanol daun kedondong (Spondias dulcis Parkinson) di timbang dengan menggunakan neraca analitik hingga mencapai berat $400 \mathrm{mg}$. Ekstrak kental tersebut dimasukkan kedalam tabung Erlenmeyer kemudian dilarutkan dengan air sebanyak $200 \mathrm{ml}$. Selanjutnya, dilakukan pengenceran menggunakan air laut dengan dengan konsentrasi ekstrak sebesar 1000 ppm, 600 ppm, 400 ppm, 200 ppm, 100 ppm, 50 ppm, 10 ppm dan 0 ppm.

Pembuatan partisi $n$-Heksan dilakukan dengan menimbang $4 \mathrm{~g}$ ekstrak kental daun Kedondong dan dilarutkan dengan menggunakan air sebanyak $20 \mathrm{ml}$, setelah larut dimasukkan ke dalam corong pisah dan ditambahkan dengan $n$-Heksan sebanyak $65 \mathrm{ml}$, lalu diuapkan sampai mendapatkan ekstrak kental. Cara tersebut dilakukan juga pada pembuatan partisi Etil Asetat.

Pada tahap pengujian larva udang (Artemia salina Leach) dimasukkan 10 ekor ke dalam tabung reaksi yang sudah berisi $10 \mathrm{ml}$ konsentrasi 50 ppm, $10 \mathrm{ml}$ konsentrasi 100 ppm, $10 \mathrm{ml}$ konsentrasi 200 ppm, $10 \mathrm{ml}$ konsentrasi 400 ppm, 10 $\mathrm{ml}$ konsentrasi 600 dan $10 \mathrm{ml}$ konsentrasi 
1000 ppm, serta di buat kontrol negatif yang berisi $10 \mathrm{ml}$ air laut tanpa penambahan ekstrak. Setiap konsentrasi perlakuan dilakukan replikasi sebanyak 2 kali (duplo). Tabung reaksi dibiarkan di udara terbuka selama 24 jam. Setelah 24 jam, kemudian dihitung jumlah larva yang masih hidup pada masing-masing tabung reaksi. Kriteria standar untuk mengukur kematian larva udang yaitu apabila larva udang tidak menunjukkan pergerakan selama beberapa detik pengamatan.

\section{HASIL}

Tabel 1. Hasil Uji Penapisan Fitokimia

\begin{tabular}{ccc}
\hline No. & Golongan Kimia & Ekstrak Etanol \\
\hline 1 & Alkaloid & + \\
\hline 2 & Saponin & + \\
\hline 3 & Tanin & + \\
\hline 4 & Fenolik & + \\
\hline 5 & Flavonoid & + \\
\hline 6 & Triterpenoid & + \\
\hline 7 & Steroid & + \\
\hline 8 & Glikosida & +
\end{tabular}

Tabel 2. Hasil Maserasi Serbuk Daun Kedondong (Spondias dulcis P)

\begin{tabular}{llllll}
\hline Pelarut & $\begin{array}{l}\text { Volume } \\
\text { pada } \\
\text { filtrat } \\
(\mathrm{ml})\end{array}$ & $\begin{array}{l}\text { Perubahan } \\
\text { warna filtrat }\end{array}$ & $\begin{array}{l}\text { Warna } \\
\text { ekstrak } \\
\text { pekat }\end{array}$ & $\begin{array}{l}\text { Berat } \\
\text { ekstrak } \\
\text { pekat }(\mathrm{g})\end{array}$ & $\begin{array}{l}\text { Rendemen } \\
\text { ekstrak }(\%)\end{array}$ \\
\hline Etanol & $2500 \mathrm{ml}$ & $\begin{array}{l}\text { Hijau } \\
\text { kecoklatan } \\
\text { menjadi } \\
\text { hijau } \\
\text { kecoklatan } \\
\text { pucat }\end{array}$ & $\begin{array}{c}\text { Hijau } \\
\text { tua }\end{array}$ & $19,58 \mathrm{~g}$ & $4,351 \%$ \\
\hline
\end{tabular}

Berdasarkan Tabel 2, menunjukkan berat ekstrak pekat yang di dapatkan sebanyak 19,58 g.

Tabel 3. Penurunan laju endap darah sebelum dan setelah pengobatan

\begin{tabular}{cccc}
\hline Pelarut & Ekstrak Cair $(\mathrm{mL})$ & Ekstrak Kental $(\mathrm{g})$ & Rendemen $(\%)$ \\
\hline Etil Asetat & $10,69 \mathrm{ml}$ & $0,38 \mathrm{~g}$ & $9,5 \%$ \\
\hline n-heksan & $27,28 \mathrm{ml}$ & $0,72 \mathrm{~g}$ & $18 \%$ \\
\hline
\end{tabular}

Berdasarkan Tabel 3, menunjukkan ekstrak $n$-heksan lebih banyak di banding dengan ekstrak etil asetat. 
Tabel 4. Hasil Nilai $\mathrm{LC}_{50}$ pada Ekstrak Etanol

\begin{tabular}{ccccc}
\hline No & Konsentrasi & \% Mati & Probit & LC $_{50}$ \\
\hline 1 & 0 & 0 & 0 & \\
\hline 2 & 50 & 20 & 4,1684 & \\
\hline 3 & 100 & 50 & 5 & \\
\hline 4 & 200 & 90 & 6,2816 & \multirow{2}{*}{$56,4806 \mathrm{ppm}$} \\
\hline 5 & 400 & 100 & 8,719 & \\
\hline 6 & 600 & 100 & 8,719 & \\
\hline 7 & 1000 & 100 & 8,719 & \\
\hline
\end{tabular}

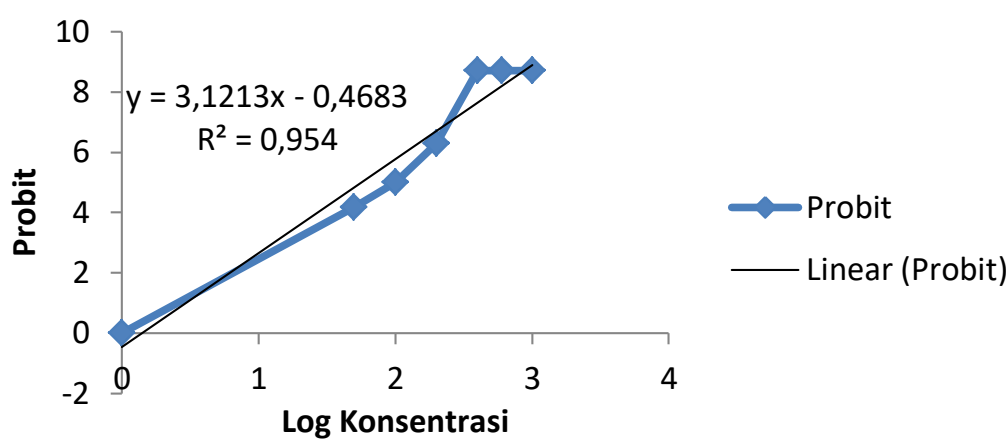

\section{Gambar 1. Regresi Linear Ekstrak Etanol}

Berdasarkan 4 dan Gambar 1, jumlah kematian larva terbanyak terdapat pada konsentrasi 400 ppm, 600 ppm dan 1000 ppm.

Tabel 5. Hasil Nilai $\mathrm{LC}_{50}$ pada Ekstrak Etil Asetat

\begin{tabular}{ccccc}
\hline No & Konsentrasi & $\%$ Mati & Probit & LC $_{50}$ \\
\hline 1 & 0 & 0 & 0 & \\
\hline 2 & 50 & 20 & 4,1647 & \\
\hline 3 & 100 & 80 & 5,8416 & \\
\hline 4 & 200 & 90 & 6,2816 & \multirow{2}{*}{$66,9730 \mathrm{ppm}$} \\
\hline 5 & 400 & 80 & 5,8416 & \\
\hline 6 & 600 & 100 & 8,719 & \\
\hline 7 & 1000 & 100 & 8,719 & \\
\hline
\end{tabular}

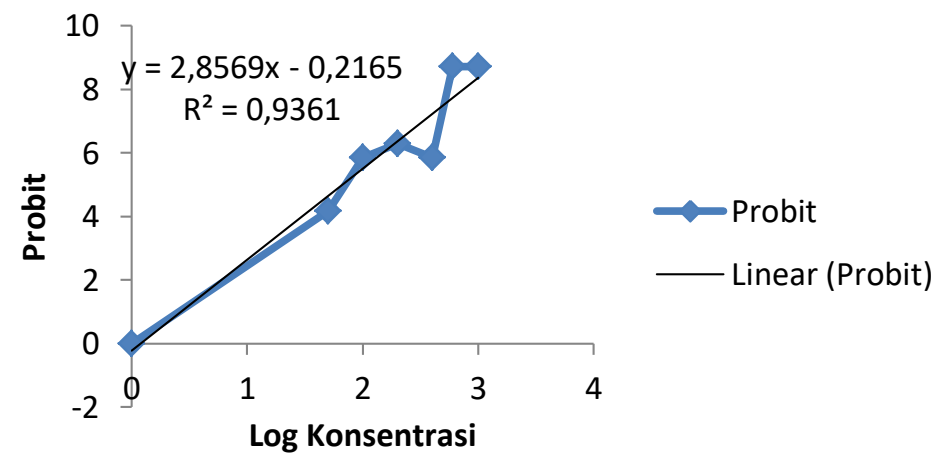

Gambar 2. Regresi Linear Ekstrak Etil Asetat 
Berdasarkan Tabel 5 dan Gambar 2, jumlah kematian larva terbanyak terdapat pada konsentrasi 600 ppm dan 1000 ppm.

Tabel 6. Hasil Nilai LC $\mathrm{C}_{50}$ pada Ekstrak $\boldsymbol{n}$-heksan

\begin{tabular}{ccccc}
\hline No & Konsentrasi & \% Mati & Probit & LC $_{\mathbf{5 0}}$ \\
\hline 1 & 0 & 0 & 0 & \\
\hline 2 & 50 & 5 & 3,3351 & \\
\hline 3 & 100 & 10 & 3,7184 & \\
\hline 4 & 200 & 10 & 3,7184 & \multirow{2}{*}{$447,7133 \mathrm{ppm}$} \\
\hline 5 & 400 & 15 & 3,9636 & \\
\hline 6 & 600 & 20 & 4,1684 & \\
\hline 7 & 1000 & 35 & 4,6147 & \\
\hline
\end{tabular}

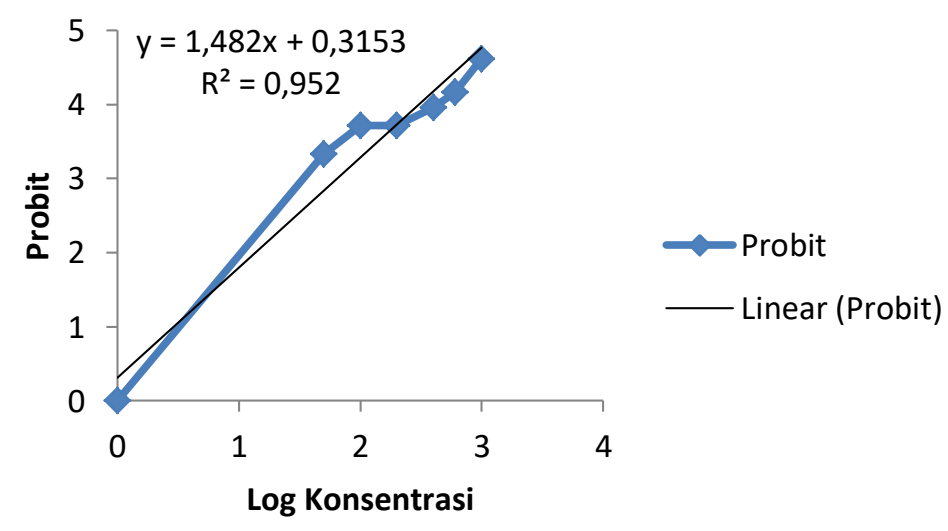

Gambar 3. Regresi Linear Ekstrak $n$-heksan

Berdasarkan Tabel 6 dan Gambar 3, jumlah kematian larva terbanyak terdapat pada konsentrasi 1000ppm.

\section{DISKUSI}

Pada uji fitokimia dilakukan untuk mengetahui kandungan senyawa aktif pada tanaman. Berdasarkan Tabel 1. Hasil analisis fitokimia terhadap ekstrak daun Kedondong (Spondias Dulcis Parkinson) diperoleh bahwa kandungan senyawa fotokimia yang terdapat didalamnya mengandung: alkaloid, saponin, tannin, fenolik, flavonoid, triterpenoid, steroid, dan glikosida. Alkaloid mempunyai fungsi sebagai antibakteri (Jazilah., 2014). Saponin mengandung glikosida dalam tanaman yang sifatnya menyerupai sabun dan dapat larut dalam air, saponin dapat menurunkan aktivitas enzim pencernaan dan penyerapan makanan (Yunia., et al. 2009). Tanin adalah senyawa polifenol yang memiliki berat molekul antara 5003000 dalton sehingga berperan sebagai antibakteri, karena dapat membentuk 
kompleks dengan protein dan interaksi hidrofibik (Makkar, 1998). Triterpenoid mempunyai manfaat penting sebagai obat tradisional, anti bakteri, anti jamur dan gangguan kesehatan (Thomson, 2004). Flavanoid mempunyai fungsi sebagai antioksidan sebagai pereduksi radikal bebas, selain itu mempunyai peran penting juga dalam menghambat mikroba atau sebagai antibiotik (Rios dan Rico, 2005). Fenol dan flavonoid berperan melindungi tubuh terhadap berbagai penyakit seperti infeksi oleh kuman, kanker, penyakit jantung koroner, diabetes, penyakit infeksi ginjal dan stroke (Astuti., et al 2011).

Penelitian ini menggunakan daun kedondong. Sebelumnya daun tersebut di determinasi terlebih dahulu untuk menghindari kesalahan dalam pengambilan spesies tanaman. Daun yang sudah disortir dan telah melalui tahap pengeringan, kemudian di blender untuk mendapatkan serbuk simplisia kering. Simplisia yang sudah berbentuk serbuk lebih mudah dalam proses ekstraksi karena semakin tinggi tingkat kehalusan maka permukaan simplisia akan semakin besar sehingga memudahkan pengambilan zat aktif dalam simplisia tersebut. Namun tingkat kehalusan yang terlalu tinggi menyebabkan pelarut akan sulit dipisahkan setelah proses ekstraksi.
Metode ekstrak yang dilakukan adalah metode maserasi. Metode maserasi lebih mudah dalam pelaksanaannya dan tidak memerlukan peralatan yang spesifik. Selain itu metode maserasi dapat digunakan untuk jenis senyawa yang tahan panas maupun yang tidak tahan panas dan dapat digunakan untuk jenis senyawa yang belum diidentifikasi. Setelah mendapatkan hasil maserasi kemudian dilakukan evaporasi dengan menggunakan water bath untuk menguapkan pelarut etanol sehingga didapatkan ekstrak kental daun kedondong.

Berdasarkan Tabel 4.2 ekstrak pekat yang di peroleh akan digunakan untuk uji selanjutnya, yaitu uji toksisitas dengan menggunakan larva udang (Artemia salina Leach) dan untuk uji fitokimia. Nilai toksisitas dapat diketahui dari jumlah kematian larva udang (Artemia salina Leach) disebabkan adanya pengaruh dari pemberian ekstrak daun Kedondong pada konsentrasi 1000 ppm, 600 ppm, 400 ppm, 200 ppm, 100 ppm, 50 ppm, dan 0 ppm pada tabung reaksi.

Ekstrak daun kedondong (Spondias dulcis Parkinson) dilakukan uji toksisitas awal untuk mengetahui ekstrak dari fase mana yang paling aktif. Dalam hal ini dicari fase mana yang memiliki toksisitas paling tinggi. Suatu ekstrak 
dapat menunjukkan aktivitas ketoksikan dalam BSLT (Brine Shrimp Lethality Test) jika ekstrak dapat menyebabkan kematian 50\% larva udang (Artemia salina Leach) pada konsentrasi kurang dari 1000 ppm (Jazilah, 2014). Dalam hal ini BSLT (Brine Shrimp Lethality Test) digunakan untuk mencari fase mana yang memiliki toksisitas paling tinggi. BSLT (Brine Shrimp Lethality Test) dilakukan terhadap ekstrak etanol dan fase fraksi yaitu fase etil asetat, dan fase $n$-heksan.

Ekstrak etanol daun kedondong dipartisi menggunakan dua pelarut yang mempunyai tingkat kepolaran yang berbeda yaitu etil asetat dan $n$-heksan. Hal ini bertujuan untuk memisahkan kelompok senyawa yang kepolarannya rendah ke pelarut $n$-heksan dan yang kepolarannya sedang ke pelarut etil asetat. Berdasarkan Tabel 4.3 diperoleh ekstrak kental etil asetat sebanyak 0,38 gram dengan persen rendemen $9,5 \%$, dan ekstrak $n$-heksan sebanyak 0,72 gram dengan persen rendemen $18 \%$.

Berdasarkan persamaan garis lurus dari masing-masing ekstrak dapat ditentukan nilai $\mathrm{LC}_{50}$ dengan cara memasukkan nilai $\mathrm{y}=5 \mathrm{ke}$ dalam persamaan garis lurus, sehingga diperoleh log konsentrasi yang menyebabkan 50\% kematian. Nilai $\mathrm{LC}_{50}$ menunjukkan konsentrasi yang menyebabkan kematian pada $50 \%$ hewan uji. Nilai $\mathrm{LC}_{50}$ merupakan indikasi untuk toksisitas senyawa. Nilai $\mathrm{LC}_{50}$ yang diperoleh mencerminkan toksisitas bahan terhadap hewan uji. Semakin besar harga nilai $\mathrm{LC}_{50}$ berarti toksisitasnya semakin kecil dan sebaliknya semakin kecil nilai $\mathrm{LC}_{50}$ maka semakin besar toksisitasnya. Ekstrak etanol memiliki nilai $\mathrm{LC}_{50}$ sebesar 56,4806 ppm, ekstrak etil asetat memiliki nilai $\mathrm{LC}_{50}$ sebesar $66,9730 \mathrm{ppm}$ dan ekstrak $n$-heksan memiliki nilai $\mathrm{LC}_{50}$ sebesar 447,7133 ppm.

Berdasarkan hasil penelitian diperoleh bahwa ekstrak etanol lebih besar daripada ekstrak etil asetat dan nheksan. Etanol merupakan pelarut polar yang dapat melarutkan senyawa-senyawa yang bersifat polar seperti golongan fenol. Kandungan senyawa yang terdapat didalam etanol merupakan senyawasenyawa yang mempunyai peran penting sebagai antimikroba/antibiotik. Etil asetat merupakan pelarut semi polar dan dapat melarutkan senyawa semi polar pada dinding sel (Harbone, 1987). Etil asetat sering digunakan sebagai pelarut karena etil asetat dapat menyari senyawasenyawa yang dapat memberikan aktivitas antibakteri diantaranya flavonoid pilohidroksi dan fenol yang lain. $n$-heksan adalah senyawa-senyawa yang bersifat nonpolar karena $n$-heksan merupakan jenis pelarut nonpolar yang akan memisahkan senyawa-senyawa nonpolar 
seperti klorofil, triterpen, lemak, dan senyawa non polar lainnya sehingga memudahkan untuk mendapatkan senyawa flavonoid.

Pernyataan diatas menunjukkan ketiga ekstrak daun kedondong yang digunakan mempunyai sifat toksik terhadap Artemia salina Leach karena memiliki nilai $\mathrm{LC}_{50}<1000 \mathrm{ppm}$. Dengan demikian, tabel tersebut menunjukkan bahwa dari masing-masing ekstrak daun kedondong memiliki sifat toksisitas yang berbeda.

Kehadiran suatu zat yang berpotensi toksik di dalam suatu tanaman, belum tentu menghasilkan keracunan. Bagi tanaman yang memiliki sifat toksik, tanaman tersebut masih bisa digunakan dalam pemakaiam yang tidak berlebihan.

\section{SIMPULAN}

Masing-masing ekstrak daun kedondong (Spondias dulcis $\mathrm{P}$ ) memiliki tingkat toksisitas terhadap Artemia salina Leach, karena memiliki nilai $\mathrm{LC}_{50}<1000$ ppm. Etanol memiliki nilai $\mathrm{LC}_{50}$ sebesar 56,4806 ppm, etil asetat sebesar 66,9730 ppm, dan $n$-heksan sebesar 447,7133. Pada penelitian ini di dapatkan hasil bahwa daun kedondong memiliki kandungan senyawa alkaloid, saponin, tanin, fenolik, flavonoid, triterpenoid, steroid, dan glikosa.

\section{DAFTAR PUSTAKA}

Sikulamay A, Suharti N, Masri M. Efek Antibakteri dari Rebusan Daun Sambiloto (Andrographis paniculata Nees) dan produk Herbal Sambiloto terhadap Staphylococcus Aureus : Jurnal Kesehatan Andalas; 2016

Murdopo. 2014. Obat Herbal Tradisional. [Diakses tanggal 15 desember 2017]. Didapat dari: djpen.kemendag.go.id

Balqis U, Rasmaidar, Marwiyah. Gambaran histopatologis penyembuhan luka bakar menggunakan daun kedondong (Spondias dulcis F.) Dan minyak kelapa pada tikus putih (Rattus norvegicus). Banda Aceh : Jurnal Medika Veterinaria, Vol. 8 No. 1; 2014

Kristianti AN, Aminah NS, Tanjung M, dan Kurniadi B. 2008. Buku Ajar Fitokimia.Surabaya: Jurusan Kimia Laboratorium Kimia Organik FMIPA Universitas

Harbone JB. 1987. Metode Fitokimia Penuntun cara menganalisis Tumbuhan, terjemah Padmawinat. Bandung: ITB press

Departemen Kesehatan RI, 2000. Pedoman Pelaksanaan Uji Klinik Obat Tradisional. Jakarta: Direktorat Jendral POM Direktur Pengawasan Obat Tradisional.

Jazilah N. 2014. Uji Toksisitas Ekstrak Daun Binahong (Anredera cordifolin (Ten.) Steenis) terhadap Larva Udang Artemia salina Leach dengan Metode Brine Shrimp Lethality Test (BSLT). Skripsi. Fakultas Sains dan Teknologi Universitas Islam Negeri Maulana Malik Ibrahim Malang, Malang.

Yunia, Elena, dkk. 2009. Pengaruh Ekstrak Daun Teklan (Eupatorium rioarium) Terhadap Mortilitas dan Perkembangan Larva Aedes aegypti: BIOMA, Vol 11, No. 1, Hal 11-17. ISSN:1410-

Makkar HPS dan Becker K. 1998. Do Tannins In Leaves of Tree And 
Shrubs Frim African And Himalayan Regions Differ In Level And Acactivity? Argoforestry systems. Hal 59-68

Thomson, RH. 1993. The Chemistri Of natural Producst.2 Edition,chapman and hall ltd.glasgow, UK.

Rios JL. dan Rico MC. 2005. Medicinal Plants and Antimicrobial Activity. Respective paper.

Astuti SM, Mimi SAM, Retno ABM, dan Awalludin R. 2011.a. Determination of Saponin Compound from Anredera cordifolia (Ten) Steenis (Binahong) to potential treatment for several deseases. Journal of Agricultural Science, Canadian Center of Science and Education. Vol 3 No 4, 2011. 224-232. 